\title{
Ethnic minorities and forest land use: a case in Can Tien National Park
}

\author{
Dân tộc thiểu số và sử dụng đất rừng: một trường hợp ở Vườn quốc gia Cần Tiên
}

\author{
DINH, Thanh Sang
}

Department of Management of Natural Resources and Environment, and Department of Land administration, Faculty of Management Sciences, Thu Dau Mot University, Binh Duong, Vietnam

\begin{abstract}
Based on the surveys in Cat Tien National Park (CTNP), this paper explored the situation of forest land use among ethnic minorities (EMs). Overall, 170 households in 6 sampled hamlets of CTNP were interviewed. In-depth interviews and the Rapid Rural Appraisal (RRA) method were implemented to obtain the data. The result showed that the more the EMs participated in natural resource management and conservation activities the less they extracted the forest land resource (Pearson Chi-Square Test, $p=0.002$ ). Moreover, the ratio of the natural resource use in terms of encroached forest land differed significantly between indigenous EMs and migrant ones (Pearson Chi-Square Test, $p=$ 0.000). It is recommended that more participation of the EMs in forest management or environmental services may be one of the effective strategies for sustainable management of the forest land in CTNP, especially in the CZs. Additionally, different management arrangements between two groups is necessary.
\end{abstract}

Kết quả nghiên cứu đã cho thấy được thực trạng sử dung đất rừng trong cộng đồng người dân tộc thiểu số tại Vườn quốc gia Cát Tiên. Phương pháp đánh giá nhanh nông thôn và phỏng vấn sâu được vận dụng để nghiên cứu 170 nông hộ mẫu thuộc 6 thôn tại vườn quốc gia. Kết quả cho thấy đồng bào dân tộc thiểu số càng tham gia các hoạt động quản lý và bảo tồn tài nguyên thì họ càng it lấn chiếm đất rừng. Hơn nữa, tỉ lệ sử dụng đất rừng nhóm dân tộc thiểu số bản địa và di cư là khác biệt. Thu hút thêm sự tham gia của đồng bào dân tộc thiểu số trong quản lý tài nguyên hay dịch vu môi trường rừng là giải pháp hữu hiệu cho công tác quản lý tài nguyên bền vững ở Vườn quốc gia Cát Tiên, đặc biệt đối với vùng lõi. Nghiên cứu cũng đề xuất cần có những giải pháp quản lý thich hợp cho từng nhóm đồng bào dân tộc thiểu số tham gia quản lý tài nguyên hay dịch vụ môi trường rừng.

Keywords: Cat Tien National Park, ethnic minorities, forest land, sustainable use

\section{Introduction}

Cat Tien National Park (CTNP), located between longitudes $107^{\circ} 09^{\prime} 05^{\prime \prime}$ and $107^{\circ} 35^{\prime} 20^{\prime \prime}$ East, and altitudes $11^{\circ} 20^{\prime} 50^{\prime \prime}$ and $11^{\circ} 50^{\prime} 20^{\prime \prime}$ North, protects one of the largest areas of the lowland tropical rainforest ecosystem with high values of biodiversity in Vietnam. Most of the area of the park lies on a basalt bedrock and five fundamentally different types of soil recognized are ferralitic soils, sandstone, old alluvium, shale and conglomerate (CTNP, 2010). There were about 2,000 residents in the core zones (CZs) and more than 200,000 people in the buffer zone (BZ) of the park. Ethnically, resident population in this park was categorised into three main groups - Kinh people, indigenous and migrant ethnic communities. The first group - Kinh people - have been lived there since before 1975; many of them from Cuu Long Delta or south - east provinces of Vietnam, and many Kinh households from northern provinces of
Vietnam settled there under the program of development of new economic zones in 1986. The indigenous ethnic minorities (IEMs) comprise Chau Ma, S'Tieng, Chau Ro, and Saray who have lived there for many generations. The migrant ethnic minorities (MEMs) consist of Tay, Nung, Dao, H'Mong, Hoa from the northern provinces and a few Kho Me from Cuu Long Delta. Each ethnic group has various histories, different traditions, and diverse material lives. However, the forest resources is endangered mainly by encroachment of forest land, illegal logging and poaching (Dinh et al., 2012). The local ethnic minorities (EMs) within and around the park have depended much on the forest resources for generations and have caused the major loss of this park (Dinh et al., 2015). So they are considered as a key element for sustainable management of the forest land resources in the area. Based on the surveys in CTNP, this paper explored the situation of forest land use among the EMs. Since 2001, many projects and programmes such as the 
programme 661, the forestland allocation programme, the programme 304, the ecotourism programme, and the payment programme for forest environmental services have been implementing in CTNP for socioeconomic development and biodiversity conservation (Dinh et al., 2015). The Prime Ministerial Decision 661/QD Tg (Programme 661) on objectives, tasks, policies and organisation for the establishment of five million hectares of new forest provided fund for reforestation, forest protection, and management efforts in 1998; this aims to compensate local communities, groups of households or individual ones for enhancing local livelihoods and contributing to sustainable forest management (GSRV, 1998).

The natural forest land in CTNP is abiotic, one of the two types of common pool resources. Common pool resources are systems that generate finite quantities of resource units so that one person's use subtracts from the quantity of resource units available to others (Ostrom et al., 1994). For example, one group of people encroached the forest land in a forest lot in CTNP and left less for others, at that time it was difficult to exclude other users from encroaching the forest land. They have two attributes; namely, being costly to exclude individuals from using the resources and the benefits consumed by one individual subtract from the benefits available to others (Ostrom et al., 1994). Moreover, overpopulation is the main problem in natural resource use found out in "The Tragedy of the Commons" (Hardin, 1968). Human beings live in a finite world, whereas goods and population cannot be maximised at the same time. Individuals have a tendency to free ride and act selfishly, so common property arrangements would bring ruin to all (Hardin, 1968). This common behavior occurs in both common pool resource and public good uses (Ostrom, 1990).

\section{Material and methods}

Overall, 170 households in six sampled hamlets of CTNP were interviewed. In-depth interviews and the Rapid Rural Appraisal (RRA) method were implemented to obtain the data through the field surveys. Other interviews were also carried out with village leaders, government officials, foresters and project staff. The data covered qualitative and quantitative information including forest resource use, socioeconomic status, management system of the park, local awareness of biodiversity conservation and forest protection. The Statistical Package for Social Sciences (SPSS) and Microsoft Excel 2010 were used to analyse both quantitative and qualitative data. Pearson Chi-Square Test was used to analyse the data.

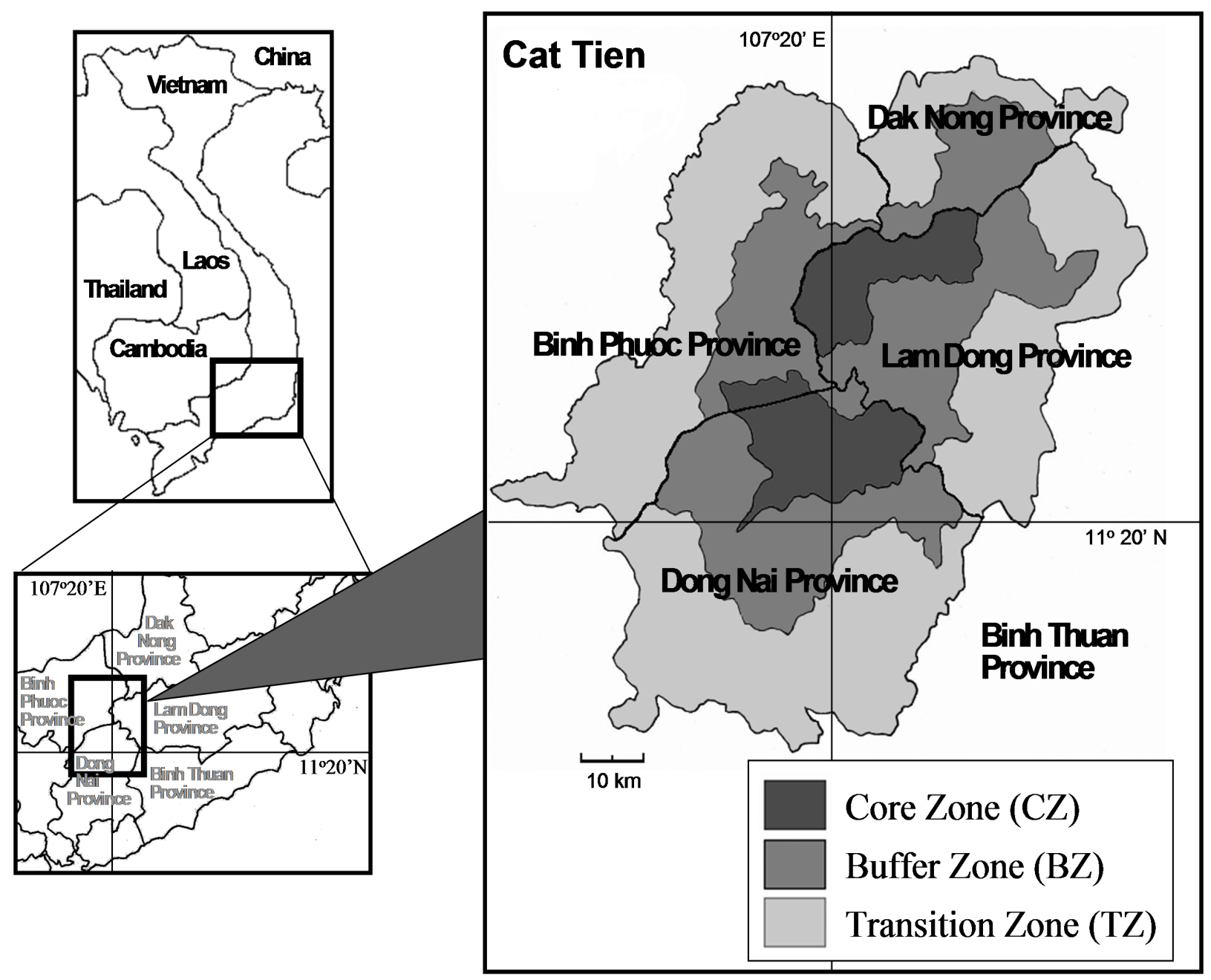

Figure 1. Location of the study sites in CTNP (Dinh et al., 2010) 


\section{Results and discussion}

Most of them, particularly EMs living within and around this park have depended much on forest resources for generations and have caused the major loss of biological resources. The EMs have livelihood strategies combining farming, collection of NTFPs, logging, livestock raising, manufacture of handicraft, aquaculture, participation in natural resource management activities, and other employment (Dinh et al., 2012). Crops cultivated in three zones of CTNP consist of cashew, rice, cassava, coffee, pepper, mandarin, jack-fruit, papaya, banana, guava, pineapple, custard-apple, mango, and longan.

Each of the household involved in one or more activities such as biodiversity conservation, forest protection and management, payment for forest environmental services, community-based ecotourism, forest regeneration, watershed management, species rescue, and environmental education under the programme 661, payment for forest environmental services (Decision 380), programme 304. They got subsidies for their participation incentive such as decision-making, planning, functioning, and management agreement. For the activities of forest protection and management or payment for environmental service, a team of EM families in one hamlet took responsibilities, on a rotational basis, for patrolling and monitoring a large natural forest plot whose sizes ranged from 100 to 200 hectares. The group was managed by a member elected by the participants. The result showed that about $48.8 \%$ households interviewed participated in forest management, conservation activities and environmental services.

The result showed that the more the EMs participated in natural resource management and conservation activities the less they extracted the forest land resource. More than $62.1 \%$ of the nonparticipants encroached forest land for cultivation, but the figure of the participants was only $38.6 \%$. The areas of encroached forest land differed significantly between the nonparticipants and the participants in natural resource management, conservation activities and environmental services (Pearson Chi-Square Test, $p=0.002$, table 1).

Table 1. Chi-Square Tests for analyzing encroached forest land between participants and the nonparticipants

\begin{tabular}{|c|c|c|c|c|c|}
\hline & Value & $d f$ & Asymp. Sig. (2-sided) & Exact Sig. (2-sided) & Exact Sig. (1-sided) \\
\hline Pearson Chi-Square & $9.396^{a}$ & 1 & .002 & & \\
\hline Continuity Correction ${ }^{\mathrm{b}}$ & 8.479 & 1 & .004 & & \\
\hline Likelihood Ratio & 9.484 & 1 & .002 & & \\
\hline Fisher's Exact Test & & & & .003 & .002 \\
\hline Linear-by-Linear Association & 9.341 & 1 & .002 & & \\
\hline N of Valid Cases ${ }^{b}$ & 170 & & & & \\
\hline
\end{tabular}

Notes: a. 0 cells (.0\%) have expected count less than 5 . The minimum expected count is $41.01 ; b$. Computed only for a $2 \times 2$ table

The area of cultivated land played a very important role in the local people's livelihoods as it is the area in which productive activities take place. The bigger the land size is, the better opportunities for the local residents ensure food security. The average per capita area of cultivated land decreased significantly from the CZs to the transitiona zone (TZ): CZs 3.8 ha (16 times larger than that in TZ), BZ 1.23 ha (5 times larger than that in TZ), TZ 0.24 ha (Dinh et al., 2012). The total encroached forest land in three zones was 67.68 ha (approximately 0.8 ha per surveyed household). The people in the BZ had the largest encroached area per household (1 ha), the residents in the $T Z$ the smallest (0.34 ha per household), the ones in the CZs had 0.63 ha (Dinh et al., 2012). All of the encroached forest land in this situation came from the forest area in the CZs of CTNP.
Many EM households surveyed encroached the forest land in the CZs of the park. Overall, the ethnic minorities in the reserve extracted and used encroached forest land to cultivate crops $(49.4 \%$ of the total interviewed households). Approximately $35.3 \%$ of the surveyed households of IEMs encroached forest land, whilst 100\% of households of MEMs did this activity. The table 2 showed that the ratio of use of the natural resources in terms of encroached forest land differed significantly between the IEMs and the MEMs (Pearson Chi-Square Test, $p=0.000$ ). Hence, the forest land use and conservation impacts were likely to be different between two these groups. 
Table 2. Chi-Square Tests for analyzing encroached forest land between IEMs and MEMs

\begin{tabular}{|c|c|c|c|c|c|}
\hline & Value & df & Asymp. Sig. (2-sided) & Exact Sig. (2-sided) & Exact Sig. (1-sided) \\
\hline Pearson Chi-Square & $48.419^{a}$ & 1 & .000 & & \\
\hline Continuity Correction ${ }^{b}$ & 45.867 & 1 & .000 & & \\
\hline Likelihood Ratio & 62.875 & 1 & .000 & & \\
\hline Fisher's Exact Test & & & & .000 & .000 \\
\hline Linear-by-Linear Association & 48.134 & 1 & .000 & & \\
\hline$N$ of Valid Cases ${ }^{b}$ & 170 & & & & \\
\hline
\end{tabular}

Notes: $a$. 0 cells (.0\%) have expected count less than 5. The minimum expected count is $18.28 ;$ b. Computed only for a $2 \times 2$ table

As mentioned above, some of EMs encroached the forest land in a forest lot in CTNP and left less for others, at that time it was difficult to exclude other residents from encroaching the forest land, especially people in the CZs. So, CTNP should take into account in excluding individuals from using the forest land illegally and finding out the sustainable use of this resource. The local participation approach should aim at managing the forest land resource not only by state actors but also by local EMs.

\section{Conclusions}

In conclusion, more MEMs as well as more households who did not involve in natural resource management, conservation activities and environmental services encroached forest land illegally. It is recommended that more participation of the EMs in forest management or environmental survices may be one of the effective strategies for sustainable management of the forest land in CTNP. The approach of their participation should aim at involving the EMs not only in planned use of the forest land resource but also in the process of sustainable conservation management of CTNP, especially in the CZs. Group-based arrangements would promote collaborative management and collective actions. So, different management arrangements between two groups are necessary.

\section{References}

[1] Cat Tien National Park, 2010. Annual report in 2010, Dong Nai Province, Vietnam.

[2] Dinh, T.S., Ogata, K. and Yabe, M., 2010. Contribution of forest resources to local people's income: A case study in Cat Tien Biosphere Reserve, Vietnam. Journal of the Faculty of Agriculture, Kyushu University 55(2):397-402.

[3] Dinh, T.S., Hyakumura, K. and Ogata, K., 2012. Livelihoods and Local Ecological Knowledge in Cat Tien Biosphere Reserve, Vietnam: Opportunities and Challenges for Biodiversity Conservation. In Natarajan, I. The Biosphere, ISBN 978-953-51-02922, InTech, chapter 13: 261-284, DOI: 10.5772/33021.

[4] Dinh, T.S., 2013. Participation of ethnic minorities in management and use of natural resources: A case study of Cat Tien Biosphere Reserve, Vietnam. Dissertation, Kyushu University, Japan.

[5] Dinh, T.S., Sato, N. and Ogata, K., 2015. Ethnic minorities and collaborative forest management: a case from Vietnam. Asian Academic Research Journal of Multidisciplinary. 1(33):258-284

[6] Government of the Socialist Republic of Vietnam (GSRV), 1998. Decision No. 661/QD-TTg on objectives, tasks, policy and organisation of the 5 million ha afforest project. Hanoi, Vietnam.

[7] Hardin, G., 1968. The Tragedy of the Commons. Science 162 (3859), 1243-1248, American Association for the Advancement of Science, United State of America.

[8] Ostrom, E., 1990. Governing the commons: the evolution of institutions for collective action. Cambridge University Press, Cambridge, United Kingdom.

[9] Ostrom, E., Gardner, R. and Walker, J., 1994. Rules, games, and common-pool resources. Ann Arbor, University of Michigan Press. 